\title{
KLAN POLITIK: STUDI TENTANG RIVALITAS CALEG KELUARGA PADJALANGI DAN HALID PADA PEMILU SERENTAK 2019
}

\author{
Riswandi $^{1}$, Reskiyanti Nurdin ${ }^{2}$, Anggriani Alamsyah ${ }^{3}$ \\ ${ }_{1,2,3}$ Program Studi Ilmu Politik UIN Alauddin Makassar \\ Email: ${ }^{1}$ mahawandi1@gmail.com, ${ }^{1}$ reski.saja@gmail.com, ${ }^{2}$ \\ anggriani.alamsyah@uin-alauddin.ac.id ${ }^{3}$
}

\begin{abstract}
Abstrak
Studi ini membahas orientasi, perilaku dan strategi yang diimplementasikan oleh dua klan yaitu klan Padjalangi dan Klan Nurdin Halid, yang lebih berfokus kepada anak mereka yakni Andi Izman Maulana Padjalangi dan Andi Muhammad Zunnun Armin Nurdin Halid yang melakukan rivalitas pada pemilu serentak 2019, DPRD Provinsi Dapil 7 Kabupaten Bone. Studi ini juga menggunakan metode kualitatif dengan analisis deskriptif. Pengumpulan data menggunakan teknik observasi, wawancara, studi dokumen - dokumen dengan menggunakan teori klan politik, , pendekatan perilaku, pemilih dan modal sosial. Hasil penelitian ini menunjukkan tiga variable dalam menjawab rumusan masalah, yaitu :Perilaku Politik Izman Padjalangi adalah ketegasan dalam memimpin dan perilaku merakyat. Dan Perilaku Politik Zunnun Halid adalah sikapnya yang lebih cenderung untuk menyelesaikan masalah dengan cara bermusyawarah. Orientasi Politik Izman Padjalangi adalah Peningkatan sumber daya manusia. Dan Orientasi Politik Zunnun Halid adalah penerapan pendidikan. Strategi Politik Izman Padjalangi adalah sosialisasi dan perintah untuk memilih dirinya yang berasal dari orang tuanya. Dan Strategi Politik Zunnun Halid adalah melakukan pendekatan ke tengah - tengah masyarakat, tokoh-tokoh masyarakat, tokoh agama, adat, politik, pemuda dan menjadi segmentasi yang dituju oleh Zunnun dan Izman untuk meraih dukungan di tengah-tengah masyarakat.
\end{abstract}

\section{Kata Kunci:}

Klan Politik, Klan Padjalangi, Klan Halid, Pemilu 2019

\begin{abstract}
This study discussed the orientation, behavior and strategy implemented by two clans, the Padjalangi clan and the Nurdin Halid clan, which were more focused on their children namely Andi Izman Maulana Padjalangi and Andi Muhammad Zunnun Armin Nurdin Halid who carried out rivalry in the 2019 simultaneous elections, DPRD Dapil Province 7 Regency of Bone. This study also used qualitative methods with descriptive analysis. Data collection used observation techniques, interviews, study of documents using political clan theory, behavioral approaches, voters and social capital. The results of this study indicated three variables in answering the formulation of the problem, namely: Izman Padjalangi Political Behavior was firmness in leading and popular behavior and the Political Behavior of Zunnun Halid was his attitude which was more inclined to resolve the problem by way of deliberation. Izman Padjalangi's political orientation was an increase in human resources. And Zunnun Halid's political orientation was the application of education. Izman Padjalangi's Political Strategy was socialization and orders to choose him who comes from his parents. And Zunnun Halid's Political Strategy was to approach the middle of the community, community
\end{abstract}


leaders, religious leaders, customs, politics, youth and be the segmentation that was aimed by Zunnun and Izman to gain support in the midst of society.

Keywords:

Political Clan, Padjalangi's Clan, Halid's Clan, 2019 Election

\section{Pendahuluan}

Brian Barry mendefinisikan demokrasi sebagai metode untuk menentukan isi dari hukum atau peraturan yang mengikat lainnya "legally binding decisions" yang mana preferensi warga memiliki koneksi formal outputnya dan preferensi tersebut diperhitungkan secara adil. Definisi ini menyiratkan bahwa dalam sebuah sistem demokratis, preferensi warga secara adil diperhitungkan dalam proses pengambilan keputusan dan terefleksi dalam hukum dan kebijakan-kebijakan pemerintah. ${ }^{1}$ Demokrasi adalah sebuah sistem pemerintahan yang baik, karena mengandung asas-asas yang sesuai dengan kebutuhan masyarakat dan mengikutkan masyarakat dalam pesta pemilihan umum. Sistem pemerintahan dikategorikan sebagai demokratis bukan hanya karena masyarakat melalui pemilu yang periodik, tetapi juga karena sistem tersebut terbuka untuk partisipasi bagi kelompok-kelompok marginal atau yang tersubordinasi. Melalui eksistensi dari mekanisme yang yang sesuai dengan demokrasi seperti inilah, apa yang disebut sebagai demokrasi prosedur menjadi demokrasi yang melibatkan rakyat, di mana di dalamnya masyarakat sipil bisa memilih pemimpin sesuai dengan kehendaknya.

Selain untuk memilih pejabat publik dan membentuk pemerintahan, pemilu juga memiliki fungsi untuk menyalurkan aspirasi rakyat, sarana membatasi perilaku dan kebijakan pemerintah, sarana elit melakukan kontrol terhadap rakyat, memberi legitimasi kekuasaan, dan sarana pendidikan politik. Fungsi penyalur aspirasi rakyat terkait dengan fungsi rekrutmen politisi. Para politisi direkrut oleh partai politik untuk bertarung dalam pemilu guna menduduki jabatan politik. Untuk dapat menang dalam pemilu, para kandidat tersebut berusaha menyerap aspirasi rakyat untuk dituangkan dalam bentuk program yang ditawarkan kepada para pemilih. Idealnya terdapat saluran komunikasi dua arah antara para politisi dengan konstituen, di mana konstituen dapat

\section{(2011), h. 9 .}

${ }_{1}$ Mudiyati Rahmatunnisa, "Desentralisasi dan Demokrasi" dalam Jurnal Governance Vol. 1, No. 2 
menyalurkan aspirasinya dan sebaliknya para politisi dapat menunjukkan komitmennya. $^{2}$

Di negara yang belum maju demokrasinya, fungsi ini kurang menonjol. Di Indonesia berdasarkan pengalaman pemilu 1999, 2004, 2009, 2014 dan 2019 menunjukkan bahwa kompetisi terjadi bukan berkaitan dengan program melainkan lebih pada figur kandidat. Hal ini terutama disebabkan oleh ketidakjelasan dan tidak adanya perbedaan yang tajam pada program-program yang ditawarkan partai politik peserta pemilu. Maka referensi yang paling mudah bagi pemilih untuk menentukan pilihannya dalam pemilu adalah figur kandidat.

Figur kandidat pun sejauh ini, terutama di daerah, diwarnai oleh pertarungan antar figur dari klan politik (dinasti) yang berbeda. Klan politik sendiri dapat dipahami sebagai serangkaian strategis politik manusia yang bertujuan untuk memperoleh kekuasaan tersebut tetap berada dipihaknya dengan cara mewariskan kekuasaan yang sudah dimiliki kepada orang lain yang mempunyai hubungan keluarga dengan pemegang kekuasaan sebelumnya.

Klan politik bisa juga disebut politik dinasti, hanya saja penamaanya yang berbeda tapi substansinya tetap sama yaitu orang dari keluarga tertentu menduduki kursi pemerintahan lalu mereka menunjuk orang dari keluarganya untuk menduduki juga kursi pemerintahan. Klan politik dapat diartikan sebagai sebuah kekuasaan politik yang dijalankan oleh sebuah keluarga ataupun sekelompok orang yang memiliki keterkaitan dengan hubungan keluarga. Klan politik sangat indentik dengan kekuasaan yang diwariskan secara turun temurun dari ayah kepada anak dan seterusnya, agar kekuasaan tetap berada di lingkaran keluarga.

Rivalitas calon legislatif (caleg) klan politik dapat diartikan sebagai rivalitas caleg dari keluarga tertentu yang selalu bertarung dalam pemilihan umum. Para caleg dari keluarga yang berkuasa biasanya mempunyai hubungan sebagai anak, saudara perempuan, saudara laki-laki dan sebagainya yang masih mempunyai hubungan kekeluargaan. Rivalitas caleg selalu mewarnai kontestasi dalam pemilihan umum tapi ketika caleg yang maju dan menang selalu berada dalam keluarga-keluarga tertentu, hal ini tentu akan mempengaruhi kualitas demokrasi yang ada di Indonesia.

2 Adi Susila, "Analisis Pemilu 2009 di Kabupaten Bekasi” dalam Jurnal FISIP: Madani, Vol. 11, No.1 (2010), h. 19. 
Studi ini diangkat akibat menggejalanya klan politik yang dilakukan oleh keluarga Padjalangi dan keluarga Halid di Kabupaten Bone. Nama Padjalangi yang identik dengan Bupati Bone dan nama Halid yang identik dengan ketua partai politik Golkar di Sulawesi Selatan. Hal ini membuktikan bahwa keluarganya yang memiliki nama akhiran dari mereka memiliki kekuatan politik yang signifikan untuk bisa berkompetisi dalam menduduki jabatan politik di Kabupaten Bone, Provinsi Sulawesi Selatan. Studi ini mencoba untuk menganalisis rivalitas kekuatan caleg keluarga Padjalangi dan Halid dalam merebut suara rakyat pada Pemilu Serentak 2019 tepatnya Pemilihan Umum Anggota Dewan Perwakilan Rakyat Daerah (DPRD) Provinsi Sulawesi Selatan di daerah pemilihan 7 Kabupaten Bone. Dengan menguraikan analisis hadirnya klan politik khususnya di tingkat lokal, studi ini memberikan perkembangan pemahaman fenomena klan politik dalam kehidupan demokrasi Indonesia saat ini.

Untuk mengkerangkai tulisan ini, maka ada tiga pertanyaan yang berusaha dijawab, yakni bagaimana orientasi politik Andi Izman Maulana Padjalangi dan Andi Muhammad Zunnun Armin Nurdin Halid?; Bagaimana perilaku politik Andi Izman Maulana Padjalangi dan Andi Muhammad Zunnun Armin Nurdin Halid?; Bagaimana strategi politik Andi Izman Maulana Padjalangi dan Andi Muhammad Zunnun Armin Nurdin Halid dalam merebut suara rakyat pada pemilu serentak 2019?.

\section{Tinjauan Pustaka}

Untuk menghindari pengulangan hasil temuan yang membahas permasalahan yang sama, maka peneliti kali ini akan menggunakan hasil temuan penelitian-penelitian terdahulu yang relevan untuk dijadikan bahan perbandingan selanjutnya. Adapun penelitian yang dimaksud di antaranya adalah Masda Putri Amelia menulis tentang "Membangun Dinasti Politik Melalui Penguatan Jejaring Kekuasaan Pada Walikota Probolinggo" menjelaskan bahwa dinasti politik banyak dibangun di beberapa daerah di Indonesia. Dinasti politik merupakan kekuasaan yang dipegang secara turun-temurun dalam satu garis keturunan dan kerabat dekat. Hal ini ditandai dengan tersebarnya jejaring kekuasaan melalui trah politik pendahulunya dengan cara penunjukan anak, istri, paman dan semacamnya untuk menduduki pos-pos strategis dalam partai (lembaga) politik. Biasanya ini adalah cara agar sanak famili tersebut bisa dengan mudah meraih jabatan publik baik sebagai Bupati/ Wakil Bupati (eksekutif) maupun 
sebagai anggota Perwakilan Rakyat/DPRD. Hal ini dapat menghambat sistem demokrasi karena tidak memberikan peluang bagi masyarakat luas untuk ikut serta dalam proses politik.

Dinasti politik di daerah dapat dilihat dari hubungan aktor-aktor dalam struktur politik, yang mana terdapat hubungan keluarga di antara mereka. Substruktur yaitu walikota sebagai lembaga eksekutif yang juga didukung oleh suami beserta putranya dengan menduduki jabatan-jabatan infrastruktur. Beberapa teman dekat Walikota juga menduduki posisi-posisi dalam infrastruktur yaitu sebagai kelompok kepentingan, dalam hal sebagai elit ekonomi dan elit agama. Keluarga beserta teman dekat Walikota memiliki sumber-sumber kekuasaan yang dapat mempengaruhi masyarakat sehingga kedudukan dari para elite politik tersebut sangat terlihat dalam masyarakat. Dengan demikian maka dapat membantu Walikota dalam membangun dinasti politik. ${ }^{3}$ Secara ringkas, Masda Putri Amelia fokus terhadap dinasti politik pada walikota Probolinggo yang terus berkuasa dan memberikan kekuasaan kepada keluarga dan teman-teman terdekatnya.

Selain Masda Putri Amelia, Habiba membidik klan politik yang ada di Polewali Mandar. Dalam tulisannya tentang "Klanisasi Politik Kabupaten Polewali Mandar (Studi Kasus Politik Klan H. Andi Masdar Pasmar)", Habiba menjelaskan tentang hadirnya keluarga Andi Masdar Pasmar diranah politik yang tidak pernah terhenti sampai sekarang ini, keluarga ini tidak pernah ketinggalan untuk terlibat di dunia perpolitikan di Kabupaten Polewali Mandar sehingga keluarga ini membentuk sebuah politik klan, maka dari itu yang menjadi masalah inti dari tulisan Habiba ini bagaimana pembentukan klan politik Andi Masdar Pasmar di Kabupaten Polewali Mandar dan apa yang menjadi faktor atau dasar sehingga eksis tensis keluarga Andi Masdar Pasmar tetap bertahan di ranah politik sampai saat ini.

Hasil penelitian menunjukkan bahwa klan politik keluarga Andi Masdar Pasmar dimulai dari keterlibatan Andi Masdar Pasmar dalam dunia politik, keterlibatan ini di lanjut oleh generasinya baik oleh putra putrinya, maupun saudara saudaranya.

3 Masda Putri Amelia, "Membangun Dinasti Politik Melalui Penguatan Jejaring Kekuasaan Pada Walikota Probolinggo" dalam Jurnal Politik. Muda Vol. 4, No. 3 (2015), h. 319-327. 
Keterlibatan mereka di ranah politik itu memiliki banyak jalur yang dilaluinya seperti melalui jalur legislativf, jalur partai/organisasi maupun jalur Pilkada/Pilgub. ${ }^{4}$

Sementara itu, Husman Husain dalam tulisannya "Politik Dinasti Studi Terhadap Kepemimpinan Andi Idris Galigo periode 2008-2013 di Kabupaten Bone” membahas tentang pengaruh politik dinasti Andi Idris Galigo di Kabupaten Bone serta implikasinya bagi proses demokrasi Indonesia. Hasil penelitiannya mengemukakan bahwa politik dinasti sebenarnya mempunyai dampak positif yaitu sebagai penguatan ideologis partai politik akan tetapi juga memiliki dampak negatif seperti dalam sistem politik dinasti yang di contohkan oleh Kabupaten Bone justru sebaliknya tidak mengacu pada sistem demokrasi esensial artinya bahwa aktor yang akan muncul dalam demokrasi ini berputar di sekitar itu saja, dan sangat bias ditegaskan dalam pengamatan ini bahwa politik kekerabatan telah keluar dari substansial demokrasi itu sendiri. ${ }^{5}$

Dadi Junaedi Iskandar dalam tulisannya tentang "Demokrasi, Otonomi Dan Fenomena Politik Dinasti Pada Pilkada Di Era Reformasi” menjelaskan bahwa musuh pertama republik adalah absolutisme yang mengejawantah dalam praktik pemerintahan raja-raja: politik dinasti diturunkan dari sistem politik seperti itu. Padahal dalam paham demokrasi, kekuasaan di produksi secara sosial melalui suatu mekanisme demokratis dan partisipatif, bukan diturunkan secara biologis.

Nilai-nilai dan semangat egalitarian memupus cara pandang feodal, sementara kehidupan politik rakyat harus berada dan senantiasa berada di bawah kontrol masyarakat, sehingga makna kedaulatan rakyat tercermin dalam mekanisme dan prosedur demokrasi empiris, termasuk dalam proses politik dan penyelenggaraan suatu pemilihan umum atau pilkada ini berarti, semangat kerepublikan dan semangat demokrasi menjadi unsur penting bagi penanda kedaulatan rakyat dimana emansipasi politik merupakan penanda adanya penentangan yang serius terhadap politik dinasti. Sebab, sejatinya sasaran dan substansi pemilukada merupakan suatu kesempatan memberi dan memperoleh legitimasi politik agar wajah demokrasi dan kepemimpinan

${ }^{4}$ Habiba, "Klanisasi Politik Kabupaten Polewali Mandar: Studi Kasus Politik Klan H. Andi Masdar Pasmar”. Skripsi. (Makassar: Fak. Ushuluddin, Filsafat dan Politik, UIN Alauddin, 2016), h. 58.

${ }^{5}$ Husman Husain, "Politik Dinasti Studi Terhadap Kepemimpinan Andi Idris Galigo Periode 20082013 di Kabupaten Bone”. Skripsi. (Makassar: Fak. Ushuluddin, Filsafat dan Politik UIN Alauddin, 2016), h. 47. 
lokal benar mencerminkan aspirasi rakyat di daerah dalam wujud penampilan politik yang sehat. ${ }^{6}$

Sementara itu Jumrah dalam tulisannya tentang "Dinasti Dan Monopoli Kekuasaan (Studi Terhadap Berkuasanya Bangsawan Bima Di Pemerintahan)" menjelaskan eksistensi kaum bangsawan di Bima. Kaum bangsawan ini tidak pernah ketinggalan untuk terlibat di dunia berpolitikan di Kabupaten Bima sehingga kaum Bangsawan ini membentuk politik dinasti, maka dari itu yang menjadi masalah inti dari tulisan Jumrah adalah tentang bentuk kekuasaan bangsawan di Kabupaten Bima dan bentuk penggunaan modalitas Dinda Damayanti Putri di Kabupaten Bima. Pembentukan politik dinasti dan monopoli kekuasaan bangsawan Bima dalam struktur kekuasaan, dimulai dari munculnya Sultan Abdul Kahir sebagai kesultanan bangsawan dalam politik lokal Bima. Pengaruh Sultan ini memberikan peluang munculnya Fery Zulkarnain dalam politik lokal.

Fery Zulkarnain pada mulanya menjadi Ketua DPRD Bima dan kemudian terpilih sebagai Bupati pada pilkada pada tahun 2005 dan terpilih kembali pada pilkada 2010. Ini membuka ruang bagi dominasi Bangsawan dalam politik lokal, selain Fery Zulkarnain juga terdapat beberapa saudaranya serta istrinya Dinda Damayanti Putri masuk dalam DPRD dan birokrasi lokal. Proliferasi kalangan bangsawan dalam politik lokal Bima. Pada bidang ekonomi juga jejaring kuasa bangsawan seperti pusat bisnis lokal dan area wisata di Bima. ${ }^{7}$

Dari ragam literatur yang dipaparkan di atas, penulis lebih mengarah ke rivalitas caleg klan Padjalangi dengan Halid pada Pemilu Serentak 2019 dan lebih berfokus kepada strategi yang digunakan oleh masing-masing caleg dalam meraih suara rakyat, orientasi politik Andi Izman Maulana Padjalangi dan Andi Muhammad Zunnun Armin Nurdin Halid, dan perilaku politik Andi Andi Izman Maulana Padjalangi dan Andi Muhammad Zunnun Armin Nurdin Halid.

${ }^{6}$ Dadi Junaedi Iskandar, "Demokrasi, Otonomi dan Fenomena Politik Dinasti pada Pilkada di Era Reformasi" dalam Jurnal Ilmu Administrasi:Media Pengembangan Ilmu dan Praktik Administrasi, Vol.12. No.3 (2015), h. $529-548$.

${ }^{7}$ Jumrah, "Politik Dinasti Dan Monopoli Kekuasaan Studi Terhadap Berkuasanya Bangsawan Bima Di Pemerintahan”. Skripsi. (Makassar: Fak. Ushuluddin, Filsafat dan Politik UIN Alauddin, 2016), h. 10. 


\section{Klan Politik dan Pendekatan Perilaku : Tinjauan Teoritik}

Salah satu pemikiran pokok pendekatan perilaku ialah bahwa tidak ada gunanya membahas lembaga formal, karena pembahasan seperti itu tidak banyak memberi informasi mengenai proses politik yang sebenarnya. Sebaliknya, lebih bermanfaat untuk mempelajari perilaku (behavior) manusia karena merupakan gejala yang dapat diamati. Pembahasan mengenai perilaku bisa saja terbatas pada perilaku perorangan saja, tetapi dapat juga mencakup kesatuan yang lebih besar seperti organisasi kemasyarakatan, kelompok elite, gerakan nasional atau suatu masyarakat politik (polity). ${ }^{8}$

Salah satu pelopor pendekatan perilaku ini ialah Gabriel Abraham Almond, di samping sarjana seperti David Easton, Karl Deutsch, Robert Dahl, dan David Apter. Gabriel Almond berpendapat bahwa semua sistem mempunyai struktur (institusi atau lembaga), dan unsur-unsur dari struktur ini menyelenggarakan beberapa fungsi. Fungsi ini bergantung pada sistem dan juga bergantung pada fungsi lainnya. Konsep ini sering disebut pandangan structural-functional. ${ }^{9}$ Sekalipun berbagai sistem politik berbeda satu sama lain dalam cara mengatur institusi, tetapi ada fungsi-fungsi tertentu yang diselenggarakan dalam setiap sistem politik. Hal ini memudahkan para peneliti untuk juga mempelajari kegiatan dan kehidupan politik di negara berkembang yang berbeda sejarah perkembangan, latar belakang kebudayaan, dan ideologinya. Pengamatan dilakukan terhadap bermacam-macam struktur yang menjalankan fungsi yang sama, sekalipun nama struktur itu mungkin berbeda.

Istilah "politik klan" dalam studi ini mengacu pada praktik politik yang dijalankan oleh keluarga untuk memperoleh kekuasaan. Penggunaan istilah "klan di sini juga menggambarkan hal yang sama dengan penggunaan istilah "kekerabatan politik" atau "oligarki politik" dalam studi lain. Koentjaraningrat mengartikan klan sebagai keluarga/kelompok atau suku. Dalam bahasa Gaelic Skotlandia dan Irlandia, clan berarti anak. Sementara itu kata "klan" lebih banyak digunakan dalam bidang antropologi sebagai sebuah istilah dalam analisis sistem kekerabatan yang didefinisikan sebagai

${ }^{8}$ Miriam Budiardjo, Dasar-Dasar Ilmu Politik (Jakarta: PT Gramedia Pustaka utama, 2015), h. 74.

${ }^{9}$ Ibid, h. 77. 
sebuah kelompok sosial yang permanen berdasarkan keturunan langsung atau fiktif (dugaan) dari nenek moyang yang sama. ${ }^{10}$

Selain itu, terdapat istilah yang biasa digunakan dalam menjelaskan fenomena keluarga politik, misalnya "politik dinasti", “dinasti politik", atau "dinasti” saja. Para akademisi lebih banyak menggunakan istilah-istilah ini untuk menjelaskan bagaimana politik dalam lingkaran keluarga karena definisinya yang mudah dipahami. Kamus Oxford, Advanced Learner's Dictionary mendefinisikan dynasty sebagai "a period of years during which members of a particular family rule a country". Dinasti didefinisikan sebagai suatu periode tahun di mana anggota keluarga tertentu memerintah sebuah negara. Singkatnya, bahwa dinasti adalah bagian dari produksi kekuasaan yang dilakukan oleh keluarga dalam struktur sosial dan politik yang kemudian berlanjut secara turun-temurun. ${ }^{11}$

Berdasarkan hal tersebut, sesuai tujuan studi ini yang mencoba melihat bagaimana rivalitas caleg dari keluarga Padjalangi dan Halid pada pemilu serentak 2019, maka penggunaan istilah klan politik akan lebih tepat. Walaupun secara harfiah "politik dinasti" dan politik "politik klan" cenderung memiliki kesamaan perspektif, keduanya memiliki perbedaan makna. Politik dinasti lebih tepat diartikan sebagai hasil dari kekuasaan keluarga dalam garis keturunan yang telah mendominasi dan diselenggarakan secara turun temurun, sedangkan politik klan lebih mengacu pada bagaimana keluarga menghadirkan kekuasaan.

Teori sistem klan yang berdasarkan pada hubungan darah, garis keturunan dan hubungan keluarga merupakan ilusi etnosentris yang dibangun oleh orang-orang Eropa dan Amerika Utara secara budaya. Merupakan suatu proyeksi obsesi kultural mereka, karena seperti keluarga ayah, ibu dan anak tidak universal sehingga ia menggunakan sistem kekerabatan. Misalnya seperti ia katakan, konsep keluarga tidak mesti bapak, ibu dan anak seperti yang kita ketahui". ${ }^{2}$

Menguatnya klan politik seperti ini tentu saja sangat mengkhawatirkan. Jika kecenderungan ini semakin meluas. Negara dijalankan oleh segelintir elite dari beberapa

10 Haryanto, Klanisasi Demokrasi: Politik Klan Qabhar Mudzakkar di Sulawesi Selatan (Yogyakarta: PolGov, 2014), h. 13.

${ }^{11}$ Ibid, h. 122

${ }^{12}$ Leo Agustino \& Mohammad Agus Yusoff, "Pilkada dan Pemekaran Daerah Dalam Demokrasi Lokal Indonesia: Local Strongmen dan Roving Bandits” dalam Jebat: Malaysian Journal of History, Politics and Strategic Studies, Vo. 37 (2010), h. 86-104. 
keluarga, klan, atau dinasti politik yang kuat di wilayah-wilayah tertentu, dan karenanya sangat sulit untuk mengharapkan adanya perluasan akses kekuasaan maupun proses demokrasi yang sehat dan substansial. Dari konsep Casey, Hess, dan Kurtz, kajian tentang klan politik lebih banyak menggunakan konsep dinasti politik (political dynasty), keluarga politik (political family) maupun klan politik (political kinship), namun tulisan ini menggunakan konsep klan politik. Konsep klan politik dimaksudkan untuk lebih memfokuskan pada aktivitas politik yang merekrut anggota kerabatnya dalam jabatan politik. Konsep klan politik dalam konteks ini bukan mengacu kepada dinasti dalam sistem monarki yang biasanya dilakukan secara turun-temurun, namun dalam konteks demokrasi yang dihasilkan melalui proses pemilu. ${ }^{13}$

Dari klan politik selanjutnya tentang konstituen, non-partisan dan pendukung lain membutuhkan pendekatan yang berbeda antara yang satu dengan yang lainnya. Konstituen adalah kelompok masyarakat yang diwakili dan memiliki kedekatan dengan suatu partai politik. Kelompok masyarakat ini yang merupakan basis pendukung kontestan. Konstituen mempunyai loyalitas yang paling tinggi dibandingkan dengan jenis pemilih yang lain. Sementara non-partisan adalah massa mengambang yang masih belum memutuskan partai politik apa yang mereka dukung. Non-partisan tidak mengikatkan diri dengan suatu partai politik apa pun. Biasanya jenis pemilih ini akan menjatuhkan pilihannya di akhir periode kampanye. Atau mereka malahan tidak memilih siapa pun karena mereka tidak melihat satu pun dari pilihan kontestan yang sesuai dengan harapan mereka. ${ }^{14}$

Tipe pemilih konstituen cenderung untuk memilih orang yang satu partai dengannya. Tipe pemilih non konstituen cenderung untuk memilih caleg yang berhasilkan meyankinkan dirinya baik secara ideologi maupun akal sehat. Tipe pemilih pendukung lain cenderung akan memilih caleg ketika caleg tersebut mempunyai suatu tawaran yang menarik. Berdasarkan pertimbangan bahwa dalam diri masing-masing pemilih terdapat dua orientasi sekaligus yaitu: Orientasi policy-problem-solving, dan Orientasi ideology. ${ }^{15}$ 2009), h. 39.

13 Siti R Zuhro, Demokrasi Lokal, Peran Aktor dalam Demokratisasi (Yogyakarta: Penerbit Ombak,

14 Firmanzah, Marketing Politik: Antara Pemahaman dan Realitas (Jakarta: Yayasan Pustaka Obor Indonesia, 2012), h. 110.

${ }^{15}$ Ibid, h. 113-114. 
Saat pemilih menilai caleg melalui paradigma policy-problem solving, maka mereka akan berpikiran sejauh mana para caleg dapat menawarkan program kerja yang bisa menyelesaikan permasalahan yang terjadi dalam wilayah tersebut. Pemilih akan lebih memilih caleg yang memiliki solusi terhadap permasalahan yang sedang terjadi dan visi misi yang jelas. Sementara pemilih yang lebih menilai caleg melalui paradigma ideology seorang caleg, akan melihat aspek-aspek seperti kedekatan keluarga, nilai, budaya, agama, moralitas, norma, dan emosi. Semakin dekat kedekatan caleg pemilih maka akan cenderung memberikan suaranya caleg tersebut.

\section{Tabel 1}

\section{Faktor Determinan Memilih}
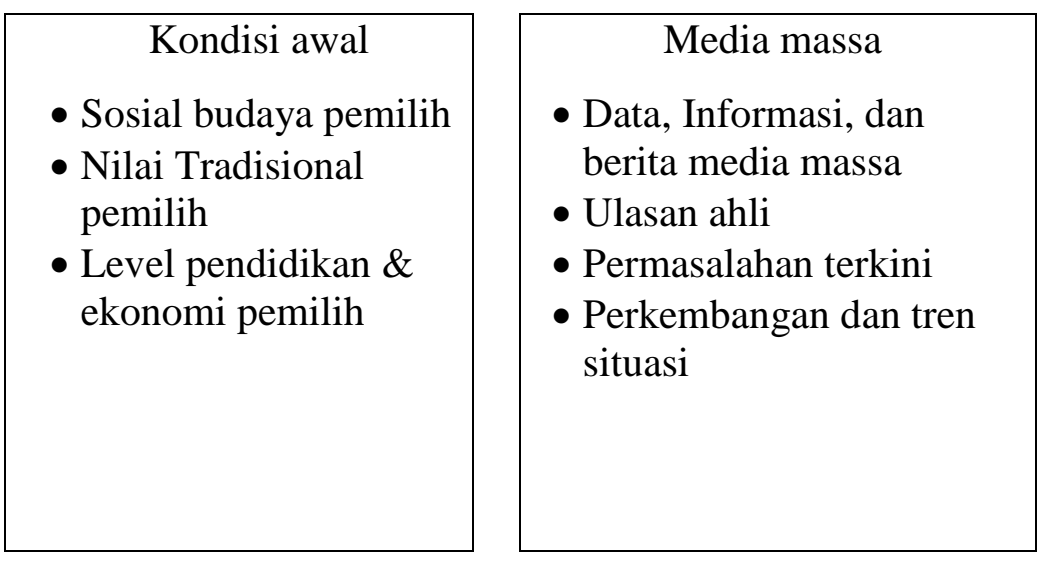

\begin{tabular}{|c|}
\hline Partai Politik / kontestan \\
- $\quad$ Catatan kinerja \& \\
- reputasi \\
- Program keting politik \\
- Sistem nilai \\
\\
\end{tabular}

Seperti terlihat dalam bagan di atas, pertimbangan (Judgment) pemilih dipengaruhi tiga faktor pada saat bersamaan: (1) kondisi awal pemilih, (2) media massa, dan (3) partai politik atau kontestan. Kondisi awal diartikan sebagai karakteristik yang melekat pada diri si pemilih. Menurut Chapman bahwa tingkat pendidikan dan ekonomi, misalnya diyakini dapat memengaruhi pemilih dalam membuat keputusan. Menurut Hofstetter kemampuan media massa untuk mendistribusikan informasi merupakan kekuatan untuk pembentukan opini publik. Opini publik sendiri sangat ditentukan oleh seberapa besar informasi yang diberikan kepada masyarakat. ${ }^{16}$

Saat pemberitaan media massa tentang caleg bersifat positif, masyarakat cenderung melihat keberadaan caleg tersebut sebagai sesuatu yang yang sangat membantu. Caleg yang mempunyai citra yang baik, berasal dari keluarga yang terkenal,

${ }^{16}$ Ibid, h. 115-118. 
mempunyai reputasi yang luar biasa, maka masyarakat akan cenderung untuk memilih caleg tersebut. Di saat itulah teori modal yang dikembangkan oleh Pierre Bourdieu memberikan pemahaman lebih dalam dalam melihat klan politik ini, yang menunjukkan teori modal itu terdiri atas model sosial, modal politik, modal ekonomi dan modal simbolik. Di teori model ini peneliti menggunakannya untuk menganalisis bagaimana rivalitas kekuatan keluarga Padjalangi dengan Halid dalam merebut suara rakyat.

Modal Sosial, sebagai sumber daya aktual dan potensial yang memiliki seseorang berasal dari jaringan sosial yang terlembagakan serta berlangsung terus menerus dalam bentuk pengakuan dan perkenalan timbal balik (atau dengan kata lain: keanggotaan dalam kelompok sosial) yang memberikan kepada anggotanya berbagai bentuk dukungan kolektif. Pierre Bourdieu juga menegaskan modal sosial sebagai sesuatu yang berhubungan satu dengan yang lain, baik ekonomi, budaya, maupun bentuk sosial kapital (modal sosial) berupa institusi lokal atau kekayaan sumber daya alam. Jadi intinya dari modalitas sosial yaitu: (1) adanya kepercayaan dari masyarakat, (2) adanya interaksi sosial dan (3) adanya jaringan yang mendukung.

Modal Politik, yaitu dukungan politik berupa dukungan partai politik (koalisi partai) dan dukungan elit-elit politik lokal dari organisasi politik dan organisasi kemasyarakatan untuk pemenangan dalam pemilu jadi, modal politik yaitu : (1) kepemilikan jabatan politisi, (2) adanya dukungan dari parpol tertentu dan (3) adanya tim sukses yang solid.

Modal Ekonomi, memiliki makna penting sebagai "penggerak" dan "pelumas" mesin politik yang dipakai. Di dalam musik kampanye misalnya membutuhkan uang yang besar untuk membiayai berbagai kebutuhan seperti mencetak poster, spanduk, membayar iklan, dan berbagai kebutuhan yang lainnya. Jadi modal ekonomi yaitu dukungan ekonomi berupa dana politik baik itu berdasarkan sumber daya dari dana pribadi dan donator, dan berdasarkan penggunaannya untuk bayar partai politik, kampanye untuk pemenangan pemilihan umum.

Modal Simbolik (seperti prestise, kehormatan atau karisma) ialah modal lainnya ketika diketahui dan diakui, melalui kategori persepsi yang memaksakan dan hubungan kekuasan simbolik yang cenderung untuk mereproduksi dan memperkuat hubungan kekuasaan yang merupakan struktur dalam ruang sosial. Singkatnya, modal simbolik 
merupakan hasil dari transformasi dari modal ekonomi, sosial dan kultural kedalam bentuk baru, dan hasil transformasi ini memiliki kekuatan besar. ${ }^{17}$

\section{Orientasi Politik Andi IM Padjalangi dan Andi MZA Nurdin Halid}

Almond dan Verba melihat bahwa dalam pandangan tentang orientasi individual terhadap objek politik terdapat tiga komponen. Komponen pertama adalah komponen kognitif, yaitu komponen yang menyangkut pengetahuan tentang politik dan kepercayaan pada politik peranan dan segala kewajibannya. Komponen kedua ialah orientasi afektif, yakni perasaan terhadap sistem politik, peranannya, para aktor, dan penampilannya. Sementara itu, komponen ketiga ialah orientasi evaluatif yaitu keputusan dan praduga tentang objek-objek politik yang secara tipikal melibatkan kombinasi standar nilai dan kriteria dengan informasi dan perasaan. ${ }^{18}$ Terhadap politik dan penyelenggaraan pemilu di Indonesia. Sistem klan politik masih berlaku dalam beberapa daerah di Kabupaten Bone merupakan salah satu aspek yang masih melandasi orientasi politik. Sistem klan tersebut adalah sistem yang turun temurun dimana jika orang tuanya adalah politisi anaknya juga bakal mengikut.

Orientasi politik tidak terlepas dari cara pandang tentang politik yang kemudian mendasari calon anggota legislatif untuk melakukan aktivitas politik yang dalam penelitian ini merupakan orientasi politik Andi Izman Maulana Padjalangi dan Andi Muhammad Zunnun Armin Nurdin Halid pada pemilu serentak 2019 pada dapil 7 Kabupaten Bone.

Berdasarkan hasil wawancara di dapatkan bahwa orientasi kognitif Andi Izman Maulana Padjalangi adalah “...Peningkatan sumber daya manusia sehingga lebih mengutamakan pendidikan, setiap pemuda mempunyai bakat dalam diri mereka masingmasing, dan sangat miris melihat para pemuda Bone yang kebanyakan tidak mengenyam pendidikan, kalau mereka tidak suka bersekolah minimal mereka mempelajari sesuatu yang sesuai dengan passionnya. Bukan hanya persoalan pendidikan tapi transparansi anggaran atau dana yang diberikan kepada pemerintah harus jelas arahnya dan digunakan untuk keperluan yang penting, menurutnya dana tersebut harus digunakan untuk sebaik-baik kepentingan rakyat, harus diperhitungkan

${ }^{17}$ Haryanto, Op.Cit, h. 17.

${ }^{18}$ Sudijono Sastroatmodjo, Perilaku Politik (Semarang: IKIP Semarang Press, 1995), h. 37-38. 
secara matang anggarannya, karena ada anggaran untuk pemerintah, pegawai pemerintahan dan dana untuk pembangunan infrastruktur. Untuk dana infrastruktur haruslah digunakan untuk tempat yang benar-benar sangat membutuhkannya seperti jalanan di beberapa desa yang sudah tidak bisa lagi di lalui dengan mobil..."19

Orientasinya yang menunjukkan indikasi yang tergolong tinggi, baik pengetahuan, frekuensi kesadaran, perasaan, dan evaluasi positif mengenai politik dan pemilu itu sendiri sehingga menghasilkan tingkat partisipasi memilih yang tinggi pula.

Sementara Orientasi afektif dapat terlihat dari hasil wawancara Andi Izman Maulana Padjalangi adalah “...Orientasi saya adalah berupa peranan untuk meningkatkan kemampuan pemuda/pemudi Bone. Saat saya menjadi anggota legislatif, saya akan berusaha sebaik-baiknya untuk menjalankan amanah yang saya dapat. Dan berusaha mencarikan an menyelesaikan permasalahan-permasalahan yang ada dalam ruang lingkup daerah saya...,20

Orientasi yang menuju pada peningkatan Sumber Daya Manusia (SDM) merupakan hal yang sangat melekat dalam diri Izman Padjalangi karena sejak lama ia menginginkan para pemuda Bone yang unggul dan cerdas, mereka harus bisa berkreativitas sendiri dalam dunia yang digelutinya. Para pemuda berhak untuk berbicara di depan umum karena itu merupakan hak politik mereka, tapi ia berharap ketika seorang pemuda berbicara di depan umum atau mengkritisi pemerintah maka pernyataannya haruslah berbobot dan dapat di pertanggungjawabkan.

Berdasarkan hasil wawancara di dapatkan bahwa orientasi evaluatif Andi Izman Maulana Padjalangi adalah sebagai berikut; “...kriteria saya adalah bidang peningkatan kemampuan pemuda demi kemajuan bangsa dan negara dan akan bekerja sebaikbaiknya untuk masyarakat Bone. Saya tidak menjanjikan program kerja apapun kepada masyarakat karena yang menentukan program kerja bukan saya tapi dari pemerintah..."21 Sementara itu orientasi evaluatif Andi Izman Maulana Padjalangi adalah “...kriteria saya adalah bidang peningkatan kemampuan pemuda demi kemajuan bangsa dan negara dan akan bekerja sebaik-baiknya untuk masyarakat Bone. Saya tidak

19 Andi Izman Maulana Padjalangi (25 tahun), Anggota Legislatif Provinsi Dapil 7 Kabupaten Bone, Wawancara, di Warkop Dominity, 25 September 2019.

${ }^{20}$ Ibid.

${ }^{21}$ Ibid. 
menjanjikan program kerja apapun kepada masyarakat karena yang menentukan program kerja bukan saya tapi dari pemerintah...,22

Sementara untuk melihat orientasi kognitif Andi Muhammad Zunnun Armin Nurdin Halid bisa diketahui dari pernyataan Nasruddin ketika penulis melakukan wawancara. $^{23}$ Orientasi dari Andi Muhammad Zunnun Armin Nurdin Halid lebih berfokus ke pendidikan saja. Menurutnya masyarakat harus tahu tentang keadaan politik saat ini. Masyarakat diharapkan tidak apatis dalam setiap pemilihan umum yang dilaksanakan, karena disinilah ajang penting untuk menentukan pemimpin yang tepat. Peran masyarakat yang sangat penting dalam bidang politik inilah yang membuat Zunnun Halid termotivasi untuk mencerdaskan masyarakat.

Sedangkan orientasi afektif Andi Muhammad Zunnun Armin Nurdin Halid adalah "Orientasi politik Zunnun Halid adalah menyelesaikan masalah yang dihadapi masyarakat, selain itu juga mengawasi program yang dijalankan pemerintah, seperti pembangunan dan lain-lain. Menurutnya 3 tugas pokok DPR adalah pengawasan, anggaran, dan legislasi." ${ }^{24}$ Partai Golkar yang sebagai kendaraan politik Andi Muhammad Zunnun Armin Nurdin Halid juga sejalan dengan orientasi evaluatifnya, bahwa "Orientasi evaluatif Andi Muhammad Zunnun Armin Nurdin Halid dengan kriterianya meningkatkan pendidikan, perekonomian dan pembangunan untuk mewakili aspirasi rakyat dan menyejahterakan masyarakat.",25

\section{Perilaku Politik Andi IM Padjalangi dan Andi MZA Nurdin Halid}

Perilaku politik dapat dirumuskan sebagai kegiatan yang berkaitan tentang proses pembuatan dan pelaksanaan keputusan politik. Interaksi antara pemerintah dan masyarakat, antar lembaga pemerintah dan antara kelompok dan individu dalam masyarakat dalam rangka proses pembuatan, pelaksanaan dan penegakan keputusan politik yang pada dasarnya merupakan perilaku politik. Berkaitan dengan perilaku politik, satu hal yang perlu dibahas adalah apa yang disebut sikap politik. Sikap merupakan kesiapan untuk bereaksi terhadap objek lingkungan tertentu sebagai suatu

${ }^{22}$ Ibid.

${ }^{23}$ Nasruddin (32 Tahun), Wakil Sekretaris Partai Golkar Provinsi Sulawesi Selatan, Wawancara, di kantor DPD Partai Golkar Provinsi Sulawesi Selatan, 23 September 2019.

${ }^{24}$ Ibid.

${ }^{25}$ Idris (26 Tahun), Panitia Pemungutan Suara Kecamatan Ulaweng, Wawancara, di kantor Kecamatan Ulaweng Kabupaten Bone, 19 September 2019. 
penghayatan terhadap objek tersebut. Sikap belum merupakan suatu tindakan atau aktivitas akan tetapi baru merupakan kecenderungan. ${ }^{26}$

\section{Andi Izman Maulana Padjalangi}

Informasi mengenai sikap Izman Padjalangi peneliti dapat langsung dari wawancara dengan Izman Padjalangi dan wakil Sekretaris Golkar Provinsi Sulawesi Selatan, adapun sikap politiknya adalah sebagai berikut.

“...Begini yah ketika saya ingin turun ke lapangan untuk sosialisasi atau kampanye saya lebih suka untuk berbaur dengan masyarakat dan berpakaian seperti yang mereka pakai. Saya orangnya memang begitu bahkan dalam keseharian juga, kalau memang tidak dalam pertemuan penting saya memakai pakaian yang biasa saja. Yah, tidak perlu untuk tampil dengan pakaian mahal. Saya sangat prihatin dengan permasalahan-permasalahan yang ada di Kabupaten Bone karena dalam beberapa kecamatan ada beberapa jalan utama yang rusak dan dari pelosok-pelosok desa sangat banyak jalanan yang rusak bahkan tidak bisa dilalui oleh kendaraan lagi hal ini mendorong saya untuk bisa memperbaiki jalan-jalan tersebut..."27

Penilaian Izman Padjalangi terhadap suatu objek didasarkan pada minat dan kebutuhannya terhadap perolehan suara. Penyesuaian diri yang dilakukan adalah dengan melakukan sosialisasi dari satu desa ke desa lainnya untuk menjalin komunikasi dan memperkenalkan diri kepada khalayak umum dan menjaga keharmonisan dengan masyarakat. Sikap politiknya berupa keinginan untuk mengatasi permasalahanpermasalahan yang ada pada wilayahnya.

Sikap politik Izman Padjalangi seperti perencanaan untuk memenangkan kontentasi pemilu, pengambilan keputusan yang tepat, dan pelaksanaan keputusan dipengaruhi oleh berbagai dimensi latar belakang yang merupakan bahan dalam pertimbangan politiknya. Faktor-faktor yang mempengaruhi perilaku politik Izman Padjalangi adalah faktor lingkungan sosial politik, yaitu keadaan sistem politik yang dimengerti dengan baik dan turun sosialisasi ke masyarakat. Dan juga mengerti keadaan sistem ekonomi, dengan baik menilai keadaan perekonomian politik masyarakat dan perputaran keuangan. Ia juga mengerti sistem budaya, sebelum turun sosialisasi ke

\footnotetext{
26 Sudijono, Op.Cit., h. 4.

27 Andi Izman Maulana Padjalangi (25 tahun), Anggota Legislatif Provinsi Dapil 7 Kabupaten Bone, Wawancara, di Warkop Dominity, 25 September 2019.
} 
masyarakat. Terakhir adalah keluarga dan teman, teman pergaulan sangat berperan terhadap pembentukan sikap politik karena mereka merupakan tempat untuk berdiskusi dan lingkungan keluarga yang sering membicarakan politik atau mengerjakan aktivitas politik akan secara langsung mempengaruhi sikap politik Izman Padjalangi. Lingkungan ini memberikan sosialisasi dan internalisasi nilai dan norma pada Izman Padjalangi dan memberikan pengalaman-pengalaman hidup.

Informasi mengenai motivasi Izman Padjalangi peneliti dapat langsung dari wawancara dengan Izman Padjalangi, adapun motivasinya adalah sebagai berikut.

“...Motivasi saya adalah ingin melihat kesejahteraan rakyat dalam bidang infrastruktur dan pendidikan terkhususnya untuk para pemuda Kabupaten Bone. Ia tidak ingin seorang pemuda mengkritisi sesuatu secara asal-asalan tetapi harus mengkritik sesuatu yang memang layak untuk di kritik. 382 Desa saya datangi dan setiap turun saya tidak pernah menjanjikan sesuatu karena hal itu merupakan hal yang terlarang bagi saya. Yang dikatakan adalah melakukan yang terbaik bagi mereka misalnya pemerintah tidak ingin membangun tower sedangkan ia menjanjikan akan membangun tower, kan tidak relavan nantinya....,28

Berdasarkan hasil wawancara yang peneliti lakukan bersama dengan informan peneliti mendapati bahwa perilaku politik dari Andi Izman Maulana Padjalangi adalah sebagai berikut.

"Perilaku politik Andi Izman Maulana Padjalangi itu masih baik-baik saja nggak ada paksaan yah seperti yang secara umumnya dilakukan oleh para caleg ia turun ke lapangan bersama tim sukses untuk sosialisasi dan kampanye."29

Perilaku politik Izman Padjalangi lebih mengarah kepada sosialisasi dan kampanye untuk mencapai suatu tujuan, serta sistem kekuasaan yang memungkinkan adanya suatu otoritas untuk mengatur kehidupan masyarakat ke arah pencapaian tujuan tersebut. Dalam sosialisasi tersebut mereka memaparkan visi dan misi mereka yang akan dilaksanakan ketika terpilih menjadi anggota legislatif, inilah yang menjadi perilaku politik ketika perilaku mereka mempunyai hubungan dengan politik. Tidak semua perilaku bisa disebut sebagai perilaku politik, hanya perilaku yang mempunyai hubungan dengan politik saja yang bisa disebut perilaku politik. Dalam hal ini perilaku

${ }^{28} \mathrm{Ibid}$.

29 Idris (26 Tahun), Panitia Pemungutan Suara Kecamatan Ulaweng, Wawancara, di Kantor Kecamatan Ulaweng Kabupaten Bone, 19 September 2019. 
politik Izman Padjalangi sangatlah jelas karena ia turun ke lapangan bersama tim suksesnya untuk meyakinkan kepada masyarakat bahwa dirinya pantas untuk mereka pilih menjadi anggota legislatif.

Informasi mengenai persepsi Izman Padjalangi peneliti dapat langsung dari wawancara dengan Izman Padjalangi, adapun persepsi politiknya adalah sebagai berikut.

“...Saya menganggap remaja itu merupakan aset bangsa yang sangat penting sehingga kemampuan mereka itu sangat dibutuhkan, mereka itu setidaknya menjadi orang yang berpendidikanlah atau dengan kata lain bersekolah, jika mereka memang tidak mau yah cukup meningkatkan passion atau kemampuan mereka..."30

Informasi mengenai harapan Izman Padjalangi peneliti dapat langsung dari wawancara dengan Izman Padjalangi, adapun harapannya adalah sebagai berikut.

“...saya menginginkan peningkatan kualitas untuk masyarakat di Kabupaten Bone khususnya untuk para pemudanya, lebih bagus kalau mereka mempunyai kreativitas di bidangnya sendiri..., 31

Situasi dan keadaan yang mempengaruhi Andi Izman Maulana secara langsung yang membuat dirinya mempunyai pendirian yang teguh untuk memantapkan jiwa dan raganya agar bisa meningkatkan kualitas masyarakat Kabupaten Bone.

\section{Andi Muhammad Zunnun Armin Nurdin Halid}

Zunnun Halid mempunyai kepribadian politik seperti mempunyai jiwa kepemimpinan yang demokratis, suka bermusyawarah, dan sebagainya. Berdasarkan hasil wawancara yang peneliti lakukan bersama dengan responden peneliti mendapati bahwa perilaku dari Zunnun Halid adalah sebagai berikut.

"Perilaku politik Zunnun Halid adalah ia suka bermusyawarah sebelum mengambil langkah dan pada waktu kampanye ia melakukan pendekatan ke tokoh masyarakat dan berdiskusi tentang strategi untuk memenangkan pemilu,

${ }^{30}$ Andi Izman Maulana Padjalangi (25 tahun), Anggota Legislatif Provinsi Dapil 7 Kabupaten Bone, Wawancara, di Warkop Dominity, 25 September 2019.

${ }^{31}$ Ibid. 
dan hal ini telah membuktikan bahwa ia mempunyai perilaku politik yang jelas.", 32

Berdasarkan hasil wawancara yang peneliti lakukan bersama dengan informan peneliti mendapati bahwa motivasi politik dari Andi Muhammad Zunnun Armin Nurdin Halid adalah sebagai berikut.

"Motivasi politik Zunnun Halid adalah ingin mensejahterahkan masyarakat Kabupaten Bone, akan lebih bagus ketika masyarakatnya berpendidikan dan pembangunan lebih baik lagi, sehingga aktivitas yang dilakukan bisa dilaksanakan dengan lancar.",33

Struktur kepribadian yang tercermin dalam motivasi Zunnun Halid, yaitu berupa hasil dari pengamatan dan penyesuaian diri dengan masyarakat.

Berdasarkan hasil wawancara yang peneliti lakukan bersama dengan informan peneliti mendapati bahwa perilaku politik dari Andi Muhammad Zunnun Armin Nurdin Halid adalah sebagai berikut.

"Perilaku politik Andi Muhammad Zunnun Armin Nurdin Halid adalah dengan turun ke lapangan tapi lebih berfokus ke tokoh masyarakat dan kepala desa sehingga ia bisa bernegosiasi." 34

Perilaku politik Zunnun Halid lebih mengarah kepada diskusi dengan tokoh masyarakat terkait strategi pemenangan untuk mencapai tujuannya. Dalam diskusi tersebut ia memaparkan visi dan misi yang akan dilaksanakan ketika terpilih menjadi anggota legislatif, inilah yang menjadi perilaku politik ketika perilaku mereka mempunyai hubungan dengan politik. Perilaku politik Zunnun Halid, dengan menemui tokoh masyarakat dan membahas mengenai strategi pemenangannya maka bisa disebut sebagai perilaku politik.

Berdasarkan hasil wawancara yang peneliti lakukan bersama dengan informan peneliti mendapati bahwa persepsi politik dari Zunnun Halid adalah sebagai berikut.

"Persepsi politik Zunnun Halid adalah menyejahterakan masyarakat Kabupaten Bone, dengan terus bekerja sebaik-baiknya demi kepentingan masyarakat." 35

${ }^{32}$ Nasruddin (32 Tahun), Wakil Sekretaris Partai Golkar Provinsi Sulawesi Selatan, Wawancara, di kantor DPD Partai Golkar Provinsi Sulawesi Selatan, 23 September 2019.

${ }^{33}$ Ibid.

${ }^{34}$ Idris (26 Tahun), Panitia Pemungutan Suara Kecamatan Ulaweng, Wawancara, di Kantor Kecamatan Ulaweng Kabupaten Bone, 19 September 2019. 
Berdasarkan hasil wawancara yang peneliti lakukan bersama dengan informan peneliti mendapati bahwa harapan dari Zunnun Halid adalah sebagai berikut.

"Harapan Zunnun Halid adalah ingin menyejahterakan masyarakat Kabupaten Bone, baik dalam bidang pembangunan maupun dalam bidang pendidikan."36

Dalam kehidupan bermasyarakat dan bernegara, setiap individu terkait dengan persoalan politik dalam arti luas. Masyarakat sebagai kumpulan individu memiliki harapan sekaligus tujuan yang hendak diwujudkan. Harapannya untuk menyejahterakan masyarakat telah menandakan bahwa ia melihat masih banyak ketimpangan yang terjadi di masyarakat Bone sehingga timbul pemikiran tersebut.

Disparitas perilaku politik Izman Padjalangi dan Zunnun Halid terlihat jelas pada motivasinya, Izman Padjalangi lebih menginginkan untuk peningkatan pengetahuan masyarakat khususnya bagi pemuda, untuk meningkatkan tidak harus berpendidikan tinggi tapi setidaknya mempunyai kemampuan yang bagus. Ia lebih suka untuk turun langsung ke masyarakat bersama dengan tim sukses yang di bentuknya ketimbang langsung berdiskusi dengan tokoh masyarakat, tokoh pemuda dan yang lainnya. Berbeda dengan Zunnun Halid yang lebih mengkhususkan kepada pendidikan masyarakat, minimal masyarakat tamat SMP. Dan pada waktu kampanye Ia lebih banyak berfokus kepada tokoh masyarakat, tokoh pemuda, pemuka agama dan sebagainya ketimbang harus bersosialisasi ke semua daerah yang ada di Kabupaten Bone.

\section{Strategi Politik Andi IM Padjalangi dan Andi MZA Nurdin Halid}

Praktik klan politik yang terjadi dalam kontestasi pemilihan umum serentak 2019 yakni adanya klan politik demokrasi antara klan Padjalangi dan Halid, tulisan ini memfokuskan pada pertarungan caleg antara Andi Izman Maulana Padjalangi yang berasal dari klan Padjalangi dan Andi Muhammad Zunnun Armin Nurdin Halid yang berasal dari klan Halid. Rumitnya rivalitas ini karena 2 calon tersebut berasal dari partai yang sama yaitu partai Golkar.

${ }^{35}$ Nasruddin (32 Tahun), Wakil Sekretaris Partai Golkar Provinsi Sulawesi Selatan, Wawancara, di kantor DPD Partai Golkar Provinsi Sulawesi Selatan, 23 September 2019.

${ }^{36}$ Ibid. 
Kompetisi politik merupakan perhelatan yang memerlukan strategi yang jitu untuk memenangkannya, semua entitas sangatlah memerlukan strategi politik. Hal ini dimaksudkan agar kemenangan politik, baik itu berupa dukungan politik maupun perolehan suara dalam pemilu bisa diperoleh secara efisien dan efektif. Proses dan dinamika yang dimaksudkan dalam tulisan ini adalah untuk melihat strategi yang dilakukan oleh Andi Izman Maulana Padjalangi dan Andi Muhammad Zunnun Armin Nurdin Halid pada pemilu serentak april 2019

\section{Andi Izman Maulana Padjalangi}

Strategi menggunakan nama keluarga sebagai modal merupakan strategi yang sangat jitu untuk meningkatkan suara, karena banyak orang yang memilih karena melihat nama akhiran seseorang. Hal inilah yang dilakukan oleh Andi IM Padjalangi dengan membawa nama besar keluarga. ${ }^{37}$

Selain itu, strategi sosialisasi juga digunakan mengingat hal ini penting bagi seorang caleg karena terkait dengan sistem pemilu yang digunakan saat ini yaitu suara terbanyak. Hal ini membutuhkan tenaga ekstra dari seorang caleg untuk dapat secara maksimal mensosialisasikan dirinya kepada masyarakat pemilih agar masyarakat dapat mengenal dirinya dan program-program yang akan dilakukan.

Selain menggunakan nama besar keluarga dan sosialisasi, door to door dan menemui tokoh masyarakat merupakan strategi yang juga dilakukan oleh Andi Izman Maulana Padjalangi. ${ }^{38}$ Metode yang dilakukan biasanya menghubungi warga yang biasanya sudah mengetahui tentang pencalonan dirinya sebagai calon anggota legislatif. Orang yang dihubungi tersebut diminta untuk memobilisasi warga untuk dikumpulkan disatu tepat dimana tempat tersebut akan didatangi oleh si caleg. Biasanya orang yang dihubungi oleh si caleg tersebut akan secara otomatis direkrut menjadi tim sukses dan akan diberi dana untuk memobilisasi warga tersebut. Oleh sebab itu biasanya di butuhkan orang-orang yang akan dijadikan koordinator di setiap wilayah yang dijadikannya target untuk mendapatkan dukungan dari masyarakat. Untuk melakukan penguatan tentang pencalonan dirinya tersebut biasanya si caleg menyerahkannya kepada koordinator yang ditunjuknya tadi.

\footnotetext{
${ }^{37}$ Yasin (22 tahun), Tokoh Pemuda, Wawancara, di UIN Alauddin Makassar, 26 September 2019.

${ }_{38}$ Nasruddin (32 Tahun), Wakil Sekretaris Partai Golkar Provinsi Sulawesi Selatan, Wawancara, di kantor DPD Partai Golkar Provinsi Sulawesi Selatan, 23 September 2019.
} 


\section{Andi Muhammad Zunnun Armin Nurdin Halid}

Salah satu trik jitu yang digunakan oleh Andi Muhammad Zunnun Armin Nurdin Halid adalah mengumpulkan orang dalam satu tempat. ${ }^{39}$ Di setiap pemilihan umum yang dilaksanakan petak-petak pemilihan anggota legislatif pun masih sangat solid dalam mendukung pilihan masing-masing kelompok, dan yang terjadi masyarakat menentukan pilihan berdasarkan pilihan dari keluarga, teman-teman, sahabat, senior dan sejenisnya. Hal senada diungkapkan oleh salah satu pemuda yang Bone yang bernama Aswandi dengan ungkapan sebagai berikut.

"Saya menggunakan hak pilih pada pemilu serentak april 2019. Saya tidak memilih berdasarkan keinginannya sendiri tapi memilih karena ada perintah dari sahabat-sahabat, senior dan keluarga yang menyuruhnya memilih..."40

Turun langsung ke lapangan merupakan salah satu strategi yang mempunyai unsur yang penting dalam menunjang keberhasilan seorang yang ikut dalam sebuah kompetisi pemilu. Dengan turun ke lapangan maka Zunnun Halid bisa melihat secara langsung hal-hal yang dibutuhkan oleh masyarakat.

Strategi door to door dari sekian banyak variasi strategi yang dimainkan oleh Zunnun Halid, pada strategi door to door masih merupakan strategi yang paling dominan digunakan. Strategi ini oleh sebagian besar masih dianggap strategi yang efektif untuk mendekatkan diri kepada para masyarakat pemilih. Asumsi mereka masyarakat pemilih saat ini membutuhkan perhatian dan salah satu bentuk perhatian yang diberikan adalah dengan mengunjungi mereka. Strategi ini merupakan metode yang dianggap ampuh.

Suhu politik pada pemilihan anggota legislatif provinsi dapil 7 Kabupaten Bone tahun 2019 itu memang sangat memanas yang menciptakan petak-petak kelompok dalam masyarakat para pendukung masing-masing calon berupaya saling meyakinkan atas pilihannya, meski demikian konstelasi politik masih aman terkendali.

Perbedaan yang paling mencolok dalam strategi Izman Padjalangi dan Zunnun Halid adalah terletak pada bantuan keluarga. Pada keluarga Padjalangi lebih banyak memberikan bantuan karena hampir di setiap desa ia sudah mempunyai suara berkat

${ }^{39}$ Aswandi (20 Tahun), Pemuda Bone, Wawancara, di Universitas Islam Negeri Alauddin Makassar, 26 September 2019.

${ }^{40}$ Ibid. 
bantuan dari keluarganya, dan bahkan dalam beberapa kecamatan yang ada di Kabupaten Bone ada yang panitia pengawas memberikan kode untuk memilih Izman Padjalangi sedangkan Zunnun Halid belum terlalu gencar dalam memperoleh suara karena ia tidak melakukan sosialisasi di semua daerah hanya beberapa daerah saja dan Ia lebih berfokus kepada diskusi denga tokoh masyarakat.

\section{Kesimpulan}

Dari pemaparan di atas dapat disimpulkan sebagai berikut; Pertama, perilaku politik Andi Izman Maulana Padjalangi adalah orangnya tegas dan lebih suka bersikap merendah atau merakyat. Ia lebih suka berbaur dengan masyarakat pada umumnya dan tidak ingin tampil dengan pakaian mahal dan sikap sombong. Dan perilaku politik Andi Muhammad Zunnun Armin Nurdin Halid adalah orangnya tegas dalam bertindak, dan suka menyelesaikan masalah dengan cara bermusyawarah, dan tampil berwibawa menurutnya adalah hal yang baik.

Kedua, orientasi politik Andi Izman Maulana Padjalangi adalah peningkatan sumber daya manusia sehingga lebih mengutamakan pendidikan, setiap pemuda mempunyai bakat dalam diri mereka masing-masing, dan sangat miris melihat para pemuda Bone yang kebanyakan tidak mengenyam pendidikan, kalau mereka tidak suka bersekolah minimal mereka mempelajari sesuatu yang sesuai dengan passionnya. Bukan hanya persoalan pendidikan tapi transparansi anggaran atau dana yang diberikan kepada pemerintah harus jelas arahnya dan digunakan untuk keperluan yang penting, menurutnya dana tersebut harus digunakan untuk sebaik-baik kepentingan rakyat, harus diperhitungkan secara matang anggarannya, karena ada anggaran untuk pemerintah, pegawai pemerintahan dan dana untuk pembangunan infrastruktur. Dan orientasi politik Andi Muhammad Zunnun Armin Nurdin Halid adalah melakukan sosialisasi terkait pentingnya pembelajaran pendidikan yang baik adalah dengan mewujudkan dan melibatkan peran masyarakat secara optimal. Para pembelajar membutuhkan motivator yang handal yang bisa membangkitkan gairah mereka dalam hal pembelajaran. Terutama dalam hal politik karena masyarakat itu harus tahu politik agar bisa memimpin dengan baik.

Ketiga, strategi politik Andi Izman Maulana Padjalangi memaparkan kepada warga bahwasanya ia akan mewakili dirinya di tingkat provinsi. Andi Izman adalah 
satu-satunya putra Bupati Bone yang mencalonkan diri di provinsi sehingga ia bisa membawa aspirasi masyarakat Bone ke provinsi dan bersinergi dengan pemerintah Bone agar masyarakat lebih sejahtera. Dan strategi politik Andi Muhammad Zunnun Armin Nurdin Halid adalah melakukan pendekatan ke tengah-tengah masyarakat, tokoh-tokoh masyarakat, tokoh agama, adat, politik, pemuda dan itu memang menjadi sasaran yang di tuju oleh Zunnun dan Izman untuk meraih dukungan di tengah-tengah masyarakat.

\section{DAFTAR PUSTAKA}

Agustino, Leo \& Mohammad Agus Yusoff, "Pilkada dan Pemekaran Daerah Dalam Demokrasi Lokal Indonesia: Local Strongmen dan Roving Bandits" dalam Jebat: Malaysian Journal of History, Politics and Strategic Studies, Vo. 37 (2010), h. 86-104.

Amelia, Masda Putri. "Membangun Dinasti Politik Melalui Penguatan Jejaring Kekuasaan Pada Walikota Probolinggo" dalam Jurnal Politik Muda Vol. 4, No. 3 (2015), h. 319-327.

Budiardjo, Miriam. Dasar-Dasar Ilmu Politik. Jakarta: PT Gramedia Pustaka utama, 2015.

Firmanzah. Marketing Politik: Antara Pemahaman Dan Realitas. Jakarta: Yayasan Pustaka Obor Indonesia, 2012.

Habiba. "Klanisasi Politik Kabupaten Polewali Mandar: Studi Kasus Politik Klan H. Andi Masdar Pasmar". Skripsi. Makassar: Fak. Ushuluddin, Filsafat dan Politik, UIN Alauddin, 2016.

Haryanto. Klanisasi Demokrasi: Politik Klan Qahhar Mudzakkar di Sulawesi Selatan. Yogyakarta: PolGov, 2014.

Husain, Husman. "Politik Dinasti Studi Terhadap Kepemimpinan Andi Idris Galigo Periode 2008-2013 di Kabupaten Bone". Skripsi. Makassar: Fak. Ushuluddin, Filsafat dan Politik UIN Alauddin, 2016.

Iskandar, Dadi Junaedi. "Demokrasi, Otonomi dan Fenomena Politik Dinasti pada Pilkada di Era Reformasi" dalam Jurnal Ilmu Administrasi:Media Pengembangan Ilmu dan Praktik Administrasi, Vol.12. No.3 (2015), h. 529 548.

Jumrah. "Politik Dinasti Dan Monopoli Kekuasaan Studi Terhadap Berkuasanya Bangsawan Bima Di Pemerintahan". Skripsi. Makassar: Fak. Ushuluddin, Filsafat dan Politik UIN Alauddin, 2016. 
Rahmatunnisa, Mudiyati. "Desentralisasi dan Demokrasi” dalam Jurnal Governance Vol. 1, No. 2 (2011), h. 1-21.

Sastroatmodjo, Sudijono. Perilaku Politik. Semarang: IKIP Semarang Press, 1995.

Susila, Adi. “Analisis Pemilu 2009 di Kabupaten Bekasi” dalam Jurnal FISIP: Madani Vol. 11, No.1 (2010).

Zuhro, Siti R. Demokrasi Lokal, Peran Aktor dalam Demokratisasi. Yogyakarta: Penerbit Ombak, 2009.

\section{Wawancara}

Andi Izman Maulana Padjalangi (25 tahun), Anggota Legislatif Provinsi Dapil 7 Kabupaten Bone, Wawancara, di Warkop Dominity, 25 September 2019.

Aswandi (20 Tahun), Pemuda Bone, Wawancara, di Universitas Islam Negeri Alauddin Makassar, 26 September 2019.

Idris (26 Tahun), Panitia Pemungutan Suara Kecamatan Ulaweng, Wawancara, di Kantor Kecamatan Ulaweng Kabupaten Bone, 19 September 2019.

Nasruddin (32 Tahun), Wakil Sekretaris Partai Golkar Provinsi Sulawesi Selatan, Wawancara, di kantor DPD Partai Golkar Provinsi Sulawesi Selatan, 23 September 2019.

Yasin (22 tahun), Tokoh Pemuda, Wawancara, di UIN Alauddin Makassar, 26 September 2019. 